\title{
Addressing climate change adaptation and mitigation in tropical wetland ecosystems of Indonesia
}

\author{
Daniel Murdiyarso and J. Boone Kauffman
}

\section{Key points}

- Tropical wetlands, especially peatlands and mangroves, are important in global carbon cycling. Indonesia has more tropical wetlands than any other country on Earth.

- Research that addresses critical information gaps and communicates the results on land use and carbon dynamics in tropical wetlands is needed to inform sound policy decisions. This work can also improve IPCC Guidelines on methodologies for greenhouse gas inventories.

- Standardised methods and protocols are needed for effective monitoring, reporting and verification of emissions from land use and land cover change in tropical wetlands.

- Low-lying coastal ecological zones are already affected by rising sea levels and other marine -related climate change effects. Mangroves are key to both climate change mitigation and adaptation.

- Conservation and reducing degradation to tropical wetlands are both sound mitigation approaches and important adaptation strategies. Mitigation procedures that preserve ecosystem resistance and resilience to climate change are recommended as cost-effective and ecologically sound adaptation strategies.

- Ecosystem-based or watershed-wide approaches provide the best lens through which communities can assess and manage with changing climate conditions.

\section{Why are tropical wetlands so important?}

Tropical wetland ecosystems, including mangroves and peatlands, provide a broad array of ecosystem services. These ecosystems are often highly productive and harbour a unique assemblage of aquatic and terrestrial biodiversity. Wetlands also play an important role in affecting the timing and delivery of water from terrestrial to aquatic ecosystems and buffer against the transmission of pollutants across this interface.

Mangroves are important sources of energy and nutrients to coral reefs, buffer coastal zones from tropical storms, and host valuable fish and wildlife nurseries. Amongst the less studied values of global significance is their function as significant global carbon pools. Because of the accumulation of carbon over several millennia, these areas are among the largest terrestrial carbon pools on Earth (Donato et al. 2011). Most mangroves in the world are found in Asia (Figure 1).

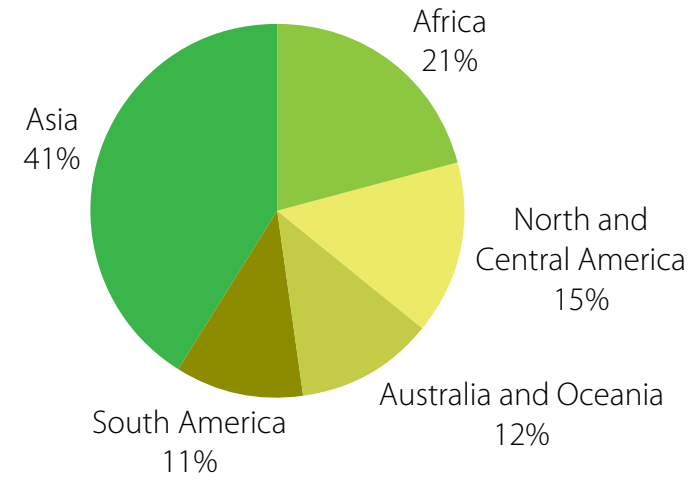

Figure 1. Worldwide distribution of mangroves, based on Giri et al. (2010)

Despite covering only about $0.25 \%$ of Earth's land surface, tropical peatlands contain around $3 \%$ of the global soil carbon stocks and at least 20\% of global peat carbon (Page et al. 2004; Page and Banks 2007). Indonesia harbours more than 20 Mha peatlands (WI 2003, 2004, 2006), with carbon 
stocks estimated at approximately 55 petagrammes carbon ${ }^{1}$ (Jaenicke et al. 2008). During 2000-2005, the deforestation rate in Indonesian peatlands was estimated at about 0.1 Mha per year (MoF 2007). The deforestation was largely related to establishment of unsustainable oil palm and pulpwood plantations and resulted in carbon emissions estimated at an annual rate of 660 gigagrammes of carbon (Koh et al. 2011). The most significant emissions, $63 \%$, came from peat respiration (Hergoualc'h and Verchot 2011).

With as many as 17000 islands, Indonesia harbours nearly a quarter of the world's mangroves. Yet over half of these coastal forests have been lost in the past three decades, shrinking from 4.2 Mha in 1982 to 2 Mha in 2000 (Giri et al. 2010).

The extent of tropical wetlands, the magnitude of loss, and associated socio-economic ramifications for Indonesia's wetlands are of global significance. The carbon density and rates of land cover change in these ecosystems are amongst the highest of any forest type on Earth. Therefore, addressing climate change and land use in wetland ecosystems could generate valuable new options for managing mangroves and peatlands.

\section{Science is needed}

Understanding the dynamics of carbon stocks, emissions and sequestration in these tropical wetlands would improve current uncertainties in emission factors and activity data required in the Intergovernmental Panel on Climate Change Guidelines (IPCC 2006) and subsequent National Communication processes.

Adequate approaches to quantifying these fluxes and stocks remain challenging. Standardised methods of monitoring, reporting and verification need to be developed.

To define the scientific basis needed and to address the challenges of managing these ecosystems in the face of rapidly increasing greenhouse gas emissions, a workshop was organised in Bali, Indonesia in April 2011. It was part of the Tropical Wetlands Initiative for Climate Adaptation and Mitigation (TWINCAM) project, jointly implemented by CIFOR and the United States Forest Service (USFS). The purpose of the workshop was to bring together Indonesian and international scientists from diverse backgrounds and with diverse experiences in both freshwater and coastal tropical wetlands to describe the state of the science, significant research needs and potential transdisciplinary approaches necessary to implement climate change adaptation and mitigation strategies.

$11 \mathrm{Pg}$ (petagramme $=10^{15} \mathrm{~g}$, or $1000000000000000 \mathrm{~g}$
The workshop programme included in-depth small group discussions on six themes:

1. Greenhouse gas flux processes in tropical wetlands

2. Land use, land cover and stock changes in tropical wetlands

3. Ecosystem modelling to predict future wetlands scenarios under climate change

4. Use of remote sensing for wetlands detection and monitoring

5. The Intergovernmental Panel on Climate Change Guidelines and processes in relation to tropical wetlands

6. Adaptation of wetlands to climate change and human dimensions

Many of the world's leading tropical wetlands scientists attended the workshop recognising the need for research collaboration. While the focus of discussions centred upon Indonesian wetlands, the research implications will be relevant to many tropical wetlands of the world, underscoring the global significance of the TWINCAM project.

\section{Mitigation and adaptation strategies in tropical wetlands}

The state of the science related to carbon and greenhouse gas fluxes, the dynamics of land use and land cover change, and the associated human dimensions were key components described for future research agendas relating to tropical wetlands, climate change and land use. Greenhouse gas fluxes are the complex interplay of biogeochemical processes and land use dynamics which are largely driven by decisions made by local people, industry and government policy. Modelling tools need to be developed to simulate land use trajectories and related responses to the environment. These models assist scientists and policy makers to weight development and mitigation options and their potential values in slowing climate change.

Tropical wetlands of the world are of great interest because of the numerous ecosystem services at risk and the extensive greenhouse gas emissions that arise from land conversion. These ecosystems both affect and are affected by climate change. Hence synergising mitigation and adaptation strategies and measures in tropical wetlands is a key approach.

Given the large carbon stocks of tropical wetlands, they represent a high potential economic value in carbon marketing strategies, known as 'reducing emissions from deforestation and forest degradation (REDD+)' (Murdiyarso et al. 2010). Co-benefits derived from the conservation or restoration of standing forests, such as biodiversity, aesthetics, ecotourism, 


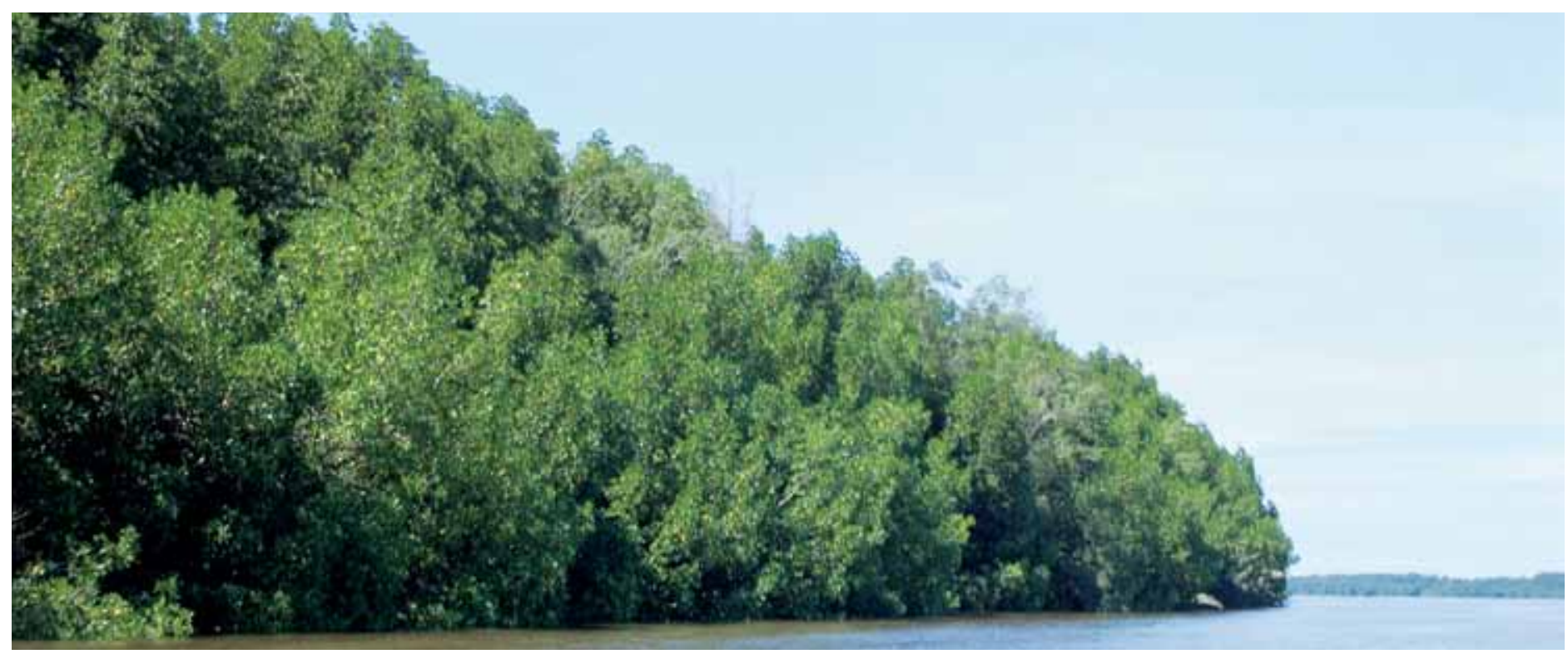

Marine mangrove formation (Rhizophora sp.) in Bunaken National Park, North Sulawesi, Indonesia (Photo by Daniel Murdiyarso)

non-timber forest products and watershed protection are additional potential financial incentives.

Given the array of tropical wetlands ecosystem services at risk, it makes sense to include them in the global, national and local climate change adaptation agendas. Coastal wetlands such as mangrove ecosystems have proven their value as buffers: They reduce vulnerability of low-lying coastal zones to damage from storm surges, tropical cyclones, and casualties from tsunamis, to some extent. Likewise, peat swamp forests function as 'landscape sponges' reducing flooding during wet seasons and releasing water during dry seasons.

Climate change impacts that most affect tropical wetlands and the people who depend on them include sea-level rise, increasing soil salinity, changes in temperature and rainfall patterns, increasing severity of cyclones, and increasing frequency and severity of El Niño Southern Oscillation events. Adaptation strategies specific to these wetlands are needed to protect ecosystem services for future generations. Mitigation procedures that preserve ecosystem resistance and resilience to climate change (such as REDD+) are also recommended as cost-effective and ecologically sound adaptation strategies.

Adaptation to the impacts of climate change must be mainstreamed into the economic development planning and implementation process. Adaptation and mitigation strategies would enhance the benefits to communities that are the most vulnerable to climate change.

In the IPCC Guidelines (IPCC 2006) there is a land use category of wetlands that is essentially limited to peatlands with limited subcategories that best suit temperate peatland management. Unfortunately, they are not as suitable for tropical wetlands, especially the unique features of tropical peatlands, mangroves and other coastal ecosystems. There are upcoming opportunities to introduce new science related to activities most relevant for tropical wetlands conservation and restoration (rewetting and revegetation). In addition, land use decisions could be better informed by the provision of new activity data and new emission factors from tropical wetlands. Knowledge generated from collaborative research on tropical wetlands in Indonesia can provide information of global relevance for the supplement of the IPCC Guidelines.

\section{Recommendations}

1. The understated roles of tropical wetlands in the existing IPCC Guidelines require substantial inputs to correct this gap. A growing body of science could greatly improve the IPCC recommendations relating to tropical freshwater and coastal wetlands.

2. Carbon-rich tropical wetland ecosystems including mangroves and peatlands should be considered high priorities in climate change adaptation and mitigation strategies throughout the world. Given its abundance of tropical wetlands, Indonesia has much to offer in the global climate agenda including the REDD+ mechanism.

3. Transdisciplinary studies are needed to build a strong science-based approach that serves Indonesia's needs for protecting its unique wetland ecosystems. National and international scientists working on wetlands issues can 
collaborate to address key policy issues surrounding tropical wetlands, climate change adaptation and mitigation.

4. Partnerships are forming amongst Indonesian and international scientists to quantify carbon stocks, sequestration and emissions. It is important to have a well coordinated research agenda that is highly relevant to the policy community and decision makers to develop mitigation and adaptation strategies that are scientifically sound, economically viable and socially acceptable.

5. The scientific community should work closely to conduct relevant studies, optimise resources and avoid duplication. Vast landscapes and several issues in Indonesia remain understudied. Communication and collaboration among agencies would minimise unnecessary overlaps. Regular meetings that facilitate exchange of knowledge should be promoted as they will assist in advancing the scientific wealth of Indonesia.

\section{Acknowledgements}

We thank the United States Department of State and the United States Agency for International Development for supporting the workshop. Practical assistance provided by the Forest Research and Development Agency (FORDA), Ministry of Forestry of the Republic of Indonesia and Sekala Foundation is also gratefully acknowledged.

\section{References}

CIFOR 2011 Proceedings of the Workshop on Tropical Wetlands. http://www.forestsclimatechange.org/workshop-on-tropicalwetland.html (25 April 2011).

Donato, D.C., Kauffman, J.B., Murdiyarso, D., Kurnianto, S., Stidham, M. and Kanninen, M. 2011 Mangroves among the most carbonrich forests in the tropics. Nature Geoscience 4:293-297. doi: 10.1038/NGEO1123.

Giri, C., Ochieng, E., Tieszen, L.L., Zhu, Z., Singh, A., Loveland, T., Masek, J. and Duke, N. 2010 Status and distribution of mangrove forests of the world using Earth observation satellite data. Global Ecology and Biogeography 20(1): 154-159. doi: 10.1111/j.1466-8238.2010.00584.x.

Hergoualc'h, K. and Verchot, L.V. 2011 Stocks and fluxes of carbon associated with land use change in Southeast Asian tropical peatlands: a review. Global Biogeological Cycles 25, GB2001. doi:10.1029/2009GB003718,2011.

Intergovernmental Panel on Climate Change (IPCC) 2006 Guidelines for national greenhouse gas inventories. Volume 4, Agriculture, forestry, and other land use, Eggleston, H.S., Buendia, L., Miwa, K., Ngara, T. and Tanabe, K. (eds). Prepared by the National Greenhouse Gas Inventories Programme, Institute of Global Environmental Studies, Japan.

Jaenicke, J., Rieley, J. O., Mott, C., Kimman, P. and Siegert, F. 2008 Determination of the amount of carbon stored in Indonesian peatlands, Geoderma 147: 151-158. doi:10.1016/j. geoderma.2008.08.008.

Koh, L.P., Miettinen, J., Liew, S.C. and Ghazoul, J. 2011 Remotely sensed evidence of tropical peatland conversion to oil palm. Proceedings of the National Academy of Sciences 108(12): 5127-5132. doi: 10.1073/pnas.1018776108.

Murdiyarso, D., Hergoualc'h, K. and Verchot, L.V. 2010 Opportunities for reducing greenhouse gas emissions in tropical peatlands. Proceedings of the National Academy of Sciences 107: 19655-19660

Page, S.E. and Rieley, J.O. 1998 Tropical peatlands: a review of their natural resource functions, with particular reference to Southeast Asia. International Peatland Journal 8:95-106.

Page, S.E., Wust R.A.J., Weiss, D., Rieley, J.O., Shotyk, W. and Limin, S. H. 2004 A record of late Pleistocene and Holocene carbon accumulation and climate change from an equatorial peat bog (Kalimantan, Indonesia): implications for past, present and future carbon dynamics, Journal of Quarternary Science 19(7): 625-635. doi:10.1002/jqs.884.

Page, S.E. and Banks, C. 2007 Tropical peatlands: distribution, extent and carbon storage-uncertainties and knowledge gaps. Peatlands International 2: 26-27.

Wetlands International (WI) 2003 Maps of peatland distribution and carbon content in Sumatra, 1990-2002, WI, Bogor, Indonesia.

Wetlands International (WI) 2004 Maps of peatland distribution and carbon content in Kalimantan, 2000-2002. WI, Bogor, Indonesia.

Wetlands International (WI) 2006 Maps of peatland distribution and carbon content in Papua, 2000-2002. WI, Bogor, Indonesia.
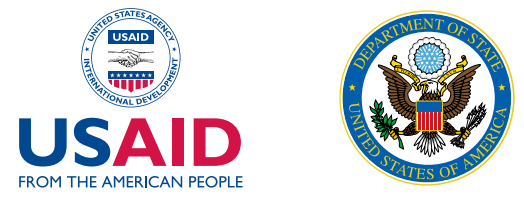

www.cifor.org

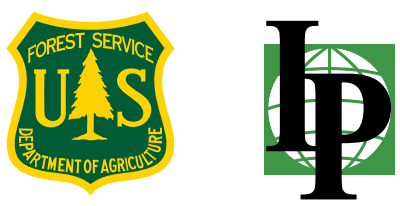

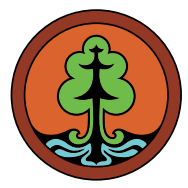

www.ForestsClimateChange.org

\section{Center for International Forestry Research}

CIFOR advances human wellbeing, environmental conservation and equity by conducting research to inform policies and practices that affect forests in developing countries. CIFOR is one of 15 centres within the Consultative Group on 